\title{
Managing Institutional Fragmentation and Time Compression in Post-Disaster Reconstruction - the Case of Bam
}

\author{
Mahmood Fayazi ${ }^{1 *}$, Fatemeh Farnaz Arefian ${ }^{2}$, Mehran Gharaati ${ }^{1}$, Cassidy Johnson ${ }^{2}$, Gonzalo \\ Lizarralde $^{1,}$ and Colin Davidson ${ }^{1 *}$
}

1. Faculté de l'aménagement, Université de Montréal, Montréal, Canada

2. The Bartlett Development Planning Unit, University College, London, UK

* Co-corresponding authors

\begin{abstract}
Several studies have revealed the difficulties often found in defining stakeholders' roles in post-disaster reconstruction projects. Insufficient and ill-timed collaboration are typically identified as the principal source of problems. Borrowing the concept of Institutional Fragmentation (IF) from the field of project management, this paper examines significant obstacles to collaboration and to sharing knowledge and experience in post-disaster reconstruction projects, revealing the causes and effects at four levels of fragmentation: the construction industry, project procurement, design and construction work. The case of the reconstruction program conducted after the 2003 earthquake in Bam (Iran), illustrates these different levels of fragmentation and their short and long-term impacts. Results show that three of the four levels of fragmentation caused unexpected outcomes during program implantation and afterwards; fragmentation increased the divergence between the many stakeholders with their interests and expectations, during and after their intervention. Conflict and confrontation between two controller organizations led to an excessive emphasis on technical requirements at the expense of heritage preservation. Results also explain how specific conditions after the disaster - such as lack of time coupled with socio-political pressures - increased fragmentation. Post-disaster reconstruction projects require systematic and comprehensive procurement to cover the interfaces that will enable tasks to be conducted effectively. The study proposes a conceptual approach to fragmentation that can help academics, practitioners, and decision-makers understand the origins and consequences of institutional fragmentation on the timely use of resources, and to develop governance structures and mechanisms that can help reduce it in post-disaster reconstruction initiatives.
\end{abstract}

Keywords: Bam (Iran); Case histories; Institutional fragmentation; Organizational design; Reconstruction; Learning organizations; Time compression.

\section{Introduction}

Lack of collaboration and scant sharing of knowledge between participants in a supply chain exist in various business sectors, including manufacturing (Christensen et al., 2001), aviation (Haller et al., 2008) and pharmaceutics (Powell, 1996). The problem is particularly acute in construction (Ofori, 2012), and also in post-disaster reconstruction (Amaratunga et al., 2009). In this paper, we examine this common challenge using the lens of Institutional Fragmentation, borrowed from the field of project management. We focus on the case of the reconstruction of the city of Bam (Iran), after the 2003 earthquake, to illustrate common obstacles to collaboration and to the sharing of knowledge and experience. The case of transitional sheltering and permanent housing reconstruction in Iran helps to explain stakeholders' roles, their sequence of interventions, and the variety of expertise, knowledge and interests they brought. This case helps us also to reveal some unexpected consequences of the generalized fragmentation that prevails in post-disaster reconstruction, enabling us to address the leading causes and potential outcomes of insufficient collaboration and sharing the knowledge and information in reconstruction projects, particularly regarding the use of the limited time available.

This article is divided into four sections. First, the concepts of institutional fragmentation and time compression in the construction sector are explained. This section also addresses critical concepts about 
stakeholders' roles in the construction industry and in post-disaster reconstruction. The methods section explains data collection and analysis strategies and tools used for the case study. The third section summarizes the main elements of the reconstruction experience in Bam after the 2003 earthquake and presents the stakeholders involved, in the order in which they intervened in the transitional sheltering and permanent housing reconstruction phases. The discussion section further elaborates on the theoretical and practical implications of the research findings and explores the unexpected outcomes of fragmentation and time compression, including the impacts a few years after the disaster. The last section summarises the main findings of the study and highlights future research avenues.

\section{Fragmentation in the construction sector}

Many studies have demonstrated that the construction sector is significantly affected by fragmentation in stakehodlers' roles and responsibilitues. The Royal Institute of British Architects (RIBA) found in 1964 that "In the traditional organisation of building, the various interests are usually confined to their own compartments. Demand has been isolated from design, demand and design from the manufacture of components and all three from construction on site" (RIBA, 1964, p. 8). The traditional building team is a "temporary grouping of independent entities brought together by certain contracts $[\ldots]$ characterized by its dispersion and its discontinuity" (Davidson, 1988, p. 512). More recently, Mohsini and Davidson (1992) found that inter-firm conflict (a consequence of fragmentation) was a contributing factor to loss of efficiency. Other authors reach similar conclusions. For Groák (1994, p.291) fragmentation is a "normal and familiar attribute of the industry". According to him, it arises from the "intrinsic complexity of the building process - in terms both of techniques and of organization" and the industry has learnt to "cope with this fragmentation, despite the problems of interfacing that it involves" (page 346). Other authors have identified four types of fragmentation in the construction sector (see Table 1):

- Construction industry fragmentation refers to the existence of a large number of design and consulting firms and contractors and enterprises that work for different (short) periods of time on any one project (Pries \& Janszen, 1995; Rutten et al., 2009; Yates \& Battersby, 2003). Numerous studies explain the principal reasons and possible consequences of this kind of fragmentation. Ofori (1992) and Alwi and Hampson (2003) argue that poor coordination among project participants leads to inefficiency, waste, and quality and safety problems. Gottlieb and Haugbølle (2013) point to the practice of competitive tendering for subcontracted work within projects - which further contributes to, and formalizes fragmentation. These authors also find that the high division of labor caused by over-specialization, and generalized subcontracting of work hinder the coordination and transfer of knowledge and learning from one actor to the next.

- Traditional procurement fragmentation creates confrontational relationships between parties. According to Ling (2003), design-bid-build contracting is a prime example of how traditional procurement causes fragmentation. The typical relationships in conventional procurement methods motivate participants to prioritize their own economic interests, seemingly regardless of whether their actions would hurt other project players or jeopardize the project as a whole. Forgues and Koskela (2009) find that traditional procurement fragmentation reinforces socio-cognitive barriers and hinders the team efficiency that is essential for the emergence of collaboration and innovation. In response, Dulaimi et al. (2002) affirm that the (less common) design-build methods enable companies to increase substantial collaboration and decrease the impact of contractual and statutory constraints. Mohsini et al. (1995), however, found that innovative procurement strategies often produce a counter effect, since they upset the habitual reliance on traditional knowledge about roles and practices. Nonetheless, current studies go so far as to suggest that "integrated design," that increases the involvement of clients in the process, encourages pre-planning of design, and enables team members to share knowledge for continuous learning (Leoto et al., 2014).

- Design project fragmentation: the involvement of different professions, accompanied by the increasing specialization of roles, leads to fragmentation in the design process (Brown \& Duguid, 2001). A number of studies point out the difficulties with the sequential approach to design development. Huovila and colleagues (1997) identify duplications and unnecessary constraints, the 
lack of leadership and accountability, and the ensuing waste of time and resources as the main symptoms of fragmentation in design processes. Löhnert et al. (2003), therefore, suggest redefining the design process, changing it from a sequential to a collaborative one, so that it becomes possible to establish long-term relationships within the design team and thence stimulate value generation. In this vein, Katsanis and Davidson (2001) propose the pertinence of, and potential for, informal groupings of professionals who are used to working together and are able to call upon each other when appropriate openings arise; they call these "Rolodex ${ }^{\odot}$ firms".

- Construction work fragmentation occurs when the realization of a project depends on the participation of numerous certified trades (Lizarralde et al., 2008). For instance, more than 20 certified professions work in the construction of a normal single-family house in Quebec, Canada (CCQ, 2015). Although the growth of the number of trades aims at increasing the quality of work, and ensuring safety and security, it formalizes fragmentation, reputedly slowing down projects, increasing costs and hiding the complete picture of the project, even to project participants. Although construction work fragmentation is common in developed countries, it can also be seen to a certain degree in developing ones as well (Lizarralde et al., 2008).

These four types of fragmentation (which can best be described here as institutionalized fragmentation) lead to difficulties in managing time in construction projects (projects are often reported as being finished long after the expected hand-over dates). In the particular case of reconstruction projects, this is an acute issue, as is explained below.

Table 1: Fragmentation; causes and effects (with emphasis on the effects on time compression)

\begin{tabular}{|c|c|c|}
\hline Fragmentation & Causes & Effects \\
\hline $\begin{array}{l}\text { Construction } \\
\text { industry } \\
\text { fragmentation }\end{array}$ & $\begin{array}{l}\text { - Competitive tendering for } \\
\text { subcontracted works (Gottlieb \& } \\
\text { Haugbølle, 2013). } \\
\text { - Extreme specialization of functions } \\
\text { and involvement of various } \\
\text { professions (Kulatunga et al., 2006). }\end{array}$ & $\begin{array}{l}\text { - Poor coordination among project } \\
\text { participants (Ofori, 1992). } \\
\text { - Specialization leads to increased } \\
\text { speed of work. } \\
\text { - Large number of participants leads } \\
\text { to delays. }\end{array}$ \\
\hline $\begin{array}{l}\text { Traditional } \\
\text { procurement } \\
\text { fragmentation }\end{array}$ & $\begin{array}{l}\text { - The design-bid-build method of } \\
\text { procurement (Ling, 2003). } \\
\text { - Temporary project settings, a strong } \\
\text { division of labor, separation of } \\
\text { design and production, and } \\
\text { competition on cost rather than on } \\
\text { optimization of value (Thomassen, } \\
\text { 2003). } \\
\text { - Isolation of contractors and } \\
\text { consultants (Gann \& Salter, 2000). }\end{array}$ & $\begin{array}{l}\text { - Stifled innovation and collaboration } \\
\text { (Latham, 1994). } \\
\text { - Reinforcement of socio-cognitive } \\
\text { barriers that hinder team efficiency } \\
\text { (Forgues \& Koskela, 2009). } \\
\text { - Confrontational relationship. } \\
\text { - Separate contracts impede rapid } \\
\text { decision-making and contract } \\
\text { procedures take time up front } \\
\text { (Mossman et al., 2010). }\end{array}$ \\
\hline $\begin{array}{l}\text { Design project } \\
\text { fragmentation }\end{array}$ & $\begin{array}{l}\text { - Sequential design rooted in } \\
\text { professional codes of practice } \\
\text { (Brown \& Duguid, 2001). } \\
\text { - Current trends for working in } \\
\text { isolated silos, with no real } \\
\text { integration of the participants' } \\
\text { collective wisdom (Lichtig, 2006). }\end{array}$ & $\begin{array}{l}\text { - Epistemic barriers, eliminating the } \\
\text { results from collaborative work } \\
\text { (Brown \& Duguid, 2001). } \\
\text { - Sub-optimal solutions. } \\
\text { - Poor constructability and } \\
\text { operability. } \\
\text { - Rework in design and construction, } \\
\text { and lack of innovation (Huovila et } \\
\text { al., 1997) } \\
\text { - Separation of design from } \\
\text { construction inhibits } \\
\text { innovation for speedier construction } \\
\text { processes }\end{array}$ \\
\hline
\end{tabular}




\begin{tabular}{lll}
\hline & - The increase of certified trades in & - Increase in prices and creation of a \\
& construction (Lizarralde et al., & vague picture of the project, \\
& hindering the transfer of information \\
& 2008). & and knowledge. \\
Construction work & & - Interfaces between trades lead to \\
fragmentation & delays & - Separation of manufacture from \\
& construction prevents time-saving \\
& innovation \\
\hline
\end{tabular}

\section{Stakeholders' roles and interests in post-disaster reconstruction}

Borrowing the stakeholder definition proposed by (Freeman, 1983), stakeholders in reconstruction projects include persons, groups and organizations, singly or as a system, who are either likely to be influenced by post-disaster interventions or who may have an influence on the project, playing different roles and having varied responsibilities (Hidayat \& Egbu, 2010; Smith, 2014). According to Davidson et al. (2007) and Asgary et al. (2006), stakeholders in a reconstruction process usually include representatives of: 1) the impacted community; 2) governments (national and local), including public and semi-public entities in a wide range of sectors and roles; 3 ) civil society organizations including NGOs, community groups, and voluntary associations; 4) private sector (i.e., business and industry groups); 5) professional groups, such as academic, training organizations, and consulting firms; and 6) media.

The diversity of stakeholders in terms of interests, experience, and resources often causes serious challenges in post-disaster reconstruction projects such as: discontinuity of interventions, fragmentation in aid delivery, and overlapping agencies' roles in the emergency response phase. Asgary et al. (2006), for instance, reveal conflicts between NGOs and explain how an international NGO with a specific focus on sheltering female-headed households provided inappropriate houses and excluded vulnerable families from aid programs after the 2003 earthquake in Bam, Iran. Similarly, Hayles (2010) notes that permanent housing reconstruction projects led by international aid organizations and NGOs are often discontinuous, and suffer from inadequate experience and limited knowledge about local conditions. In fact, coordination among stakeholders is necessary, and potential competition, rivalry, and fragmentation between them need to be considered in advance.

\section{The construction industry in a post-disaster context}

The work of the construction industry after disasters is different from regular conditions. Firstly, the recovery process does not begin with the disaster event; it "is influenced by the existing uses of space and political economy of an area" (Olshansky et al., 2008, p. 199), which are obviously outside the control of individual participants in the reconstruction program. The key difference is "time compression", which, according to Norling (2013), refers to a compressed timeframe for the reconstruction of destroyed buildings and infrastructure. Olshansky et al. (2012) comment that planning for and implementing post disaster reconstruction has to face (i) the urgency and seriousness of the situation where decisions have to be made in a compressed timeframe and (ii) in a context where many local resources have been disrupted or destroyed. As a consequence, post-disaster reconstruction is likely to suffer from escalation in construction costs (Chang et al., 2010) and shortage of available resources (Le Masurier et al., 2006), which reduce the real value of aid funds, threatening project quality, and delaying the recovery processes (Bosher \& Dainty, 2011; Ofori, 2002; Witt et al., 2014).

Difficult relationships thus typically exist between suppliers of aid and the construction industry. Aid organizations often lack appropriate technical and managerial expertise and fail to analyze local conditions and do not work either with local construction industries (VonMeding et al., 2013), or with the local informal sector (Lizarralde, 2015). Furthermore, international donors - in particular - have rigid standards for design and construction that are often disconnected from local capacities (Lizarralde, 2015). Also, the temporary character of the participation of humanitarian organizations hinders learning and sharing knowledge with construction organizations (Norling, 2013). As a consequence, the specific 
conditions after disasters exacerbate the existing fragmentation in regular construction projects and generate difficult relationships between the construction industry and other stakeholders.

\section{Research Methods}

In order to answer the question: how does fragmentation affect the reconstruction process and what are the causes of it, this study adopts an explanatory approach, based on a detailed longitudinal case study of the housing reconstruction program conducted after the earthquake that struck the city of Bam in Iran on December 26, 2003. Note that programs are considered here as a group of coordinated projects (PMI, 2015). This research project borrows the concept of institutional fragmentation to explain how the reconstruction program was organized and managed by lead agencies, notably the National Disaster Task Force (NDTF) and the Housing Foundation of the Islamic Republic (HFIR), while taking into accouint the concept of time compression. Effects on time compression - assumed to be desirable - are also noted.

In the first steps of the study, a detailed and extensive review of the project management and disaster management literature in general, and post-disaster housing reconstruction literature in particular, led to the formulation of a hypothetical proposition. The predicted pattern in this research is that four common levels of fragmentation in regular construction projects (mentioned above) cause highly significant obstacles to collaboration and to knowledge- and experience-sharing in post-disaster reconstruction projects. The main proposition, in fact, is that lessons can be learned from a case that is relevant to other reconstruction projects in other contexts. In a second stage, empirical findings from the case of Bam were matched with the predicted patterns described above. The results were then validated, adding a nuance to the theoretical proposition and contributing to theory, or what Yin (2003, p. 33) describes as an "analytical generalization."

To validate the proposition, the transitional and permanent housing reconstruction phases within the overall reconstruction program were studied to explore what was particular about each of them, who was involved, in what order did stakeholders intervene, and what expertise and knowledge were provided by, and expected of, them, drawing on first-hand experience of professional participants. Qualitative and quantitative data were collected from different sources (see table 2)

Table 2: The sources of information (qualitative and quantitative)

\begin{tabular}{|c|c|c|}
\hline Sources & Detail & Qualitative and quantitative data \\
\hline \multirow[t]{3}{*}{$\begin{array}{l}\text { Interviews } \\
\text { (Total 144 } \\
\text { interviews) }\end{array}$} & $\begin{array}{l}\text { Families } \\
\text { (89 interviews) }\end{array}$ & $\begin{array}{l}\text { - Location, size, and quality of temporary houses } \\
\text { - Location, size, and quality of houses before and after } \\
\text { the disaster } \\
\text { - Participation in housing reconstruction processes } \\
\text { - Lifestyle and social connection before and after the } \\
\text { disaster }\end{array}$ \\
\hline & $\begin{array}{l}\text { Officers and } \\
\text { authorities } \\
\text { ( } 41 \text { interviews) }\end{array}$ & $\begin{array}{l}\text { - Sheltering and housing reconstruction processes, } \\
\text { involved stakeholders, and their roles } \\
\text { - The structure of governance } \\
\text { - Impediments to the collaboration between different } \\
\text { stakeholders } \\
\text { - Conflicts between stakeholders }\end{array}$ \\
\hline & $\begin{array}{l}\text { Local masons and } \\
\text { general contractors } \\
\text { (14 interviews) }\end{array}$ & $\begin{array}{l}\text { - Traditional construction technology and materials } \\
\text { - Knowledge of disaster risk reduction requirements } \\
\text { - Lessons learned from the reconstruction experience }\end{array}$ \\
\hline \multirow[t]{2}{*}{ Documents } & Policy documents & $\begin{array}{l}\text { - Approvals of the cabinet of ministries } \\
\text { - Approvals of the Reconstruction Supervision and } \\
\text { Policymaking Association (RSPA) }\end{array}$ \\
\hline & Meeting minutes & $\begin{array}{l}\text { - Minutes of the National Disaster Task Force's } \\
\text { (NDTF) meetings }\end{array}$ \\
\hline
\end{tabular}


- Minutes of the RSPA's meetings in Bam

- Minutes of the disaster management committee's meetings in Kerman

Executive reports - The HFIR's monthly reports of the housing projects (statistics on the number of reconstructed houses, involved stakeholders in every step of reconstruction, and the amount of given loan every month)

The Bam - Temporary housing process,

Reconstruction - Participatory approach in Bam reconstruction,

Documentation - Project management in Bam reconstruction,

Project (BRDP) - Resource management in Bam reconstruction,

- Permanent housing process (planning and designing), and

- Control and monitoring techniques,

\begin{tabular}{ll}
\hline Field studies & 1) July - August 2004, 2) February 2005, 3) February 2007), 4) February- \\
(11 field trips) & March 2008, 5) November 2008, 6) January 2011, 7) June-August 2011, 8) \\
& March 2012, 9) January-February 2013, 10) May-April 2013, and 11) June - \\
& July 2014
\end{tabular}

Information about stakeholders, their roles in the reconstruction processes, their policies, decisionmaking and implementation processes was collected through 144 interviews with key participants, including affected families, the HFIR's key managers, heads of involved NGOs, heads of architectural consultancies, and local and regional representatives in the Islamic Parliament of Iran, at the time of the disaster.

In order to follow the impact of variables in the short, mid and long-terms, data collection occurred during ten years and over the course of 11 field trips to Bam (see Table 2). In order to triangulate information obtained from direct sources, more than 32 reports and six policy documents were also analyzed. Documents included project meeting minutes, press releases and construction documents, and the 11 thematic reports of the Bam Reconstruction Documentation Project (BRDP) conducted by the Housing Foundation of Islamic Republic (HFIR). Reports and policy documents, findings from field visits, and direct observations helped us verify, contradict or corroborate information collected from the interviews. Data and methodological triangulation, according to Yin (2003, p. 98) helps to "converge lines of inquiry." In fact, interviews, as a source of evidence, are often associated with personal interpretation and the distorted memories of interviewees. Likewise, incomplete and conflicting reports can also threaten the construct validity of the study. Triangulation of collected data and methods allowed us to create a coherent narrative of the events, decisions made, and actions in the reconstruction project over 10 years.

\section{Research Results}

\section{First response after the 2003 earthquake in Bam}

The devastating earthquake that shook Bam in the early hours of the morning on 26 December 2003 killed more than 22,400 people and injured more than 9,400. The population in the Bam area before the earthquake was 142,000 people. Thus it is estimated that one person in five died in the earthquake. In total there were about 75,000 people left homeless (Statistic Center of Iran, 2003).

Since the 1962 earthquake in Bou'in-Zahra in Iran, various organizations at different scales and with various responsibilities have been appointed to manage post-disaster reconstruction programs. Having suffered from major disasters, such as the 1990 Manjil-Rudbar earthquake, Iran has developed an organizational system for post-disaster reconstruction, vested in the National Disaster Task Force (NDTF) and the Housing Foundation of Islamic Republic (HFIR). The NDTF was an internal organization of the Ministry of Interior Affairs, responsible for managing the chaotic conditions after a 
disaster and for coordinating all reconstruction activities. The HFIR had long been recognized for being primarily responsible for providing affordable houses to low income families, and for post-disaster reconstruction. While there was no specific pre-disaster (operational) planning, there has been consistent learning from past experiences, and the establishment of principles underpinning reconstruction programs.

The Bam earthquake, however, was the first large-scale urban earthquake in a historic city, drawing considerable national and international attention. Immediately after the disaster, the national government set up the Reconstruction Supervision and Policymaking Association (RSPA), an interministry organization headed by the Minister of Housing and Urban Development (MHUD) with extensive power only similar to the president's cabinet (Fallahi, 2007; Fayazi, 2012; Fayazi \& Lizarralde, 2014). The RSPA consisted of the Iranian vice president, nine ministers, the governorgeneral of the Kerman province, and parliamentary representatives of Bam. It quickly appointed the HFIR as the sole housing reconstruction executor, arguing the long experience of the HFIR in low-cost housing and the provision of transitional and permanent shelters after disasters. To prevent the emergence of parallel organizations and excessive bureaucracy, the RSPA designated the HFIR to coordinate the relationship between contractors, banks, affected families, and the municipality (Babaie \& Kabiri, 2011; Omidvar et al., 2010).

In order to split the workload, authorities subdivided the affected areas - including the city of Bam, the suburban center of Baravat, and a few surrounding villages - between groups of officials at the deputy governor level. Initially, each group was responsible for managing the search and rescue operations immediately after the earthquake - a decision based on the group members' general knowledge of the area, the extent of damage and the capacity of each rescue team. These same zones were subsequently used by the HFIR for organizing the removal of rubble and, more importantly, for reconstruction planning (Arefian, 2015). To cope with the extraordinary workload - from debris removal to reconstruction - the HFIR called on its provincial branches (the "Setads").

There were several principal stakeholders within the housing reconstruction project. All had decisionmaking and supervisory roles at different levels or at different stages within the project. Before the reconstruction in Bam began, the RSPA formed the Bam Architectural and Urbanism Council (BAUC). Indeed, there was a need for a body to respond to pressure from the government and the professional bodies, as well as from the general public, to pay special attention to the architectural and urban qualities that Bam had been famous for. The BAUC was mandated to ensure that all activities in Bam were design-based and reflected the principle of safeguarding its urban fabric and cultural identity. The RSPA also identified the Kerman Construction Engineering Organization (KCEO) as the main entity responsible for providing continuous supervision over the actual construction, increasing retrofitting capabilities and avoiding any improper activities (Babaie \& Kabiri, 2011).

Thus, the RSPA, the HFIR, the BAUC and KCEO, plus a number of international, national and private companies and NGOs - each with their specific priorities - were all involved in participating in, or identifying and monitoring all the projects that had to be undertaken (see Figure 1).

\section{Figure 1 near here}

\section{Transitional Sheltering Phase}

Prior to initiating the reconstruction program, the Iranian government appointed the National Disaster Task Force (NDTF), an internal organization of the Ministry of Interior Affairs, as the principal entity responsible for policymaking and executive operations regarding transitional sheltering. In the chaotic stages of emergency relief and transitional sheltering, the NDTF invited all possible organizations, private companies, and NGOs in the country to participate in providing shelters. Based on their logistic support and experience, the HFIR and the Defense Industry (dependent on the Ministry of Defense), as well as six more private companies, agreed to provide around 28,000 units (NDTF, 2004).

The urgent need for settling survivors in safe shelters, facilitating distribution of aid and services, and 
accelerating the debris removal program, led the NDTF to make rapid decisions. Within less than three months after the earthquake, it adopted policies of providing camps of transitional shelters inside and on the outskirts of the city (Fayazi, 2012). Unforeseen challenges, however, hindered the process of implementation and forced the participants to react accordingly. In fact, by the end of March 2004 (four months after the earthquake), suppliers could only provide 2,033 units (KDTF, 2004). Common challenges included distinguishing native Bam families from opportunistic immigrants, selecting appropriate materials and construction techniques, and reaching a fair distribution of units and services. Moreover, most of the families refused to move to the temporary camps and preferred to stay in emergency tents near their remaining assets, and far from the harsh conditions on the outskirts of the city (the camps were unsafe and occupied by a large number of immigrants who arrived in Bam in the hope of obtaining financial aid and services) (Fayazi \& Lizarralde, 2014). In response, the HFIR, based on lessons learned from its previous experiences, suggested providing transitional shelters in the yards of destroyed houses (Joodi, 2011; Mahdian, 2010; NDTF, 2014).

Although this decision addressed the majority of challenges and respected the families' needs and desires, it had the immediate effect of breaking the work into short batches, requiring many short-run work packages and increasingly complex and time-consuming management, thus putting more financial pressure on the participating suppliers, forcing them to stay longer in Bam than they had anticipated, and forcing changes to their organizational structures. Because of their short time horizons, some participants could hardly accept the changes and continued providing shelters in the camps, while decreasing their commitments (KDTF, 2014). The HFIR then agreed to design and develop 7600 modest units using earthquake-resistant steel structures and masonry walls (see Figure 2). The units were planned to be used after the transitional sheltering phase alongside the permanently reconstructed houses (Ghafory-Ashtiany \& Hosseini, 2008).

The HFIR tackled the issues of higher costs and delays through: 1) involving families in the construction process; 2) establishing a distributed organizational structure in Bam, including 10 provincial branches (the Setads) and one specialized office in Tehran, and 3) assuring easy and unrestricted access to construction materials. Given the HFIR's main role as the key executor in the reconstruction of permanent houses, providing masonry-built units in the yards of destroyed houses led it to articulate the transitional sheltering and permanent housing phases into a single continuous process. In fact, the inhabitants of these units started the permanent reconstruction phase faster than those who lived in the camps (Fayazi \& Lizarralde, 2014).

Ultimately, five of the six transitional shelter suppliers agreed to provide their committed transitional units in the yards of destroyed houses, but at increased costs and over a longer period of time. Although the prefabricated units permitted settling the families close to their remaining assets, they paid virtually no attention to the possibility that affected families participate in building the units. Furthermore, not only were these units made of low quality materials but also they could hardly be adapted to be used later alongside the permanently reconstructed houses.

\section{Figure 2 near here}

Studies conducted at the end of the longitudinal research show that the HFIR's strategy led to long-term positive effects on the recovery of households, notably in the economic, social, environmental, and political dimensions (Fayazi \& Lizarralde, 2014). Proximity to their community allowed the families to communicate with their pre-disaster neighbors, sharing their worries, and adapting quickly to the adverse conditions. Permanent housing reconstruction was also facilitated by the families' participation and their close relationship with the responsible local organizations, all of which subsequently enhanced the levels of community satisfaction (Fayazi et al., 2015).

However, the transitional sheltering experience in Bam reveals several problems. First, it exacerbated the existing social gaps between the home owners who had a chance to live in the yards of their destroyed houses, and those who were tenants before the disaster and who were forced to live in the camps for almost two years. Second, this approach created a dramatic difference between those who received masonry shelters and those who received the prefabricated ones. Third, it led to there being almost 3100 unoccupied (wasted) units in the camps (KDTF, 2014). The institutional fragmentation in the transitional sheltering programs is shown in Table 3. 


\section{Permanent Housing Phase}

Given the particular condition of the disaster, and the lessons learnt from previous experiences, the RSPA established three underpinning objectives for permanent housing reconstruction in Bam: a) safeguarding its cultural identity and architectural fabric, b) constructing earthquake resistant buildings; and c) taking advantage of the participation of disaster-affected people. In order to do so, authorities adopted the owner-driven reconstruction approach (Barenstein, 2010) for mobilising disaster-affected people and developed guidelines for achieving the second and third objectives. The owner-driven reconstruction approach was successful in previous reconstruction programs, such as the Manjil reconstruction (Joodi, 2010). But beneficiaries would have to be supported during the reconstruction of their houses if the two other reconstruction objectives were to be achieved. The HFIR, as the executive body for reconstruction, invited a variety of organizations to provide financial, technical and administrative support to residents for permanent reconstruction, such as the MHUD, the BAUC, the $\mathrm{KCEO}$, and the provincial branches of the HFIR as assistant organizations (the 'Setads', mentioned above). Architectural consultancies and contractors were also invited. At one stage, about 11 of the HFIR's provincial branches, 44 architectural consultancies, and 211 contractor teams were appointed in Bam and Baravat to assist around 25,000 households in rebuilding their houses, in a process including design and construction phases (Babaie \& Kabiri, 2011). Before the start of the program, preparations were made to ensure the smooth delivery of housing units, and thus, regular monthly meetings and two workshops were held to help on this. For example, prior to opening the program to beneficiaries, local consultancies, and the MHUD developed various housing typologies that could reflect different living conditions, while also taking national seismic regulations into account (Arefian, 2015).

Working closely with beneficiaries and Setads, 28 number of architectural firms established local branches in Bam to help beneficiaries in the architectural, structural, mechanical, and electrical design of houses. These so-called "local consultancies" provided "free design and technical services" for the beneficiaries, but were in reality paid by the HFIR. Their services started when Setads and the municipality referred a beneficiary to them, and continued by preparing all required designs, site and technical plans, until the planning permission for the houses was granted and the construction activities could be started. They were not engaged in construction activities.

In order to harmonize activities by these architectural consultancies, their work had to receive approval from two controllers. The first one was another architectural consultancy firm, referred to as the 'Mother Consultancy' (MC), which had to approve architectural designs to make sure they complied with BAUC's architectural codes and recommendations. The second controller was the KCEO, which assured compliance with seismic regulations and building-related codes (Babaie \& Kabiri, 2011; Saemian \& Erfanian, 2011).

However, real-time observations during the reconstruction period, from the perspective of an architectural consultancy who worked with 2,100 beneficiaries, and from later studies, revealed significant delays in the design stage and the ensuing frustration among beneficiaries, who were desperate to return to their houses (Arefian, 2015). The delays and frustrations mainly stemmed from a conflict between the MC and the KCEO that emerged early in the design phase, causing lengthy waiting times for the local consultancies to obtain the required stamps of approval from both controllers while coping with the beneficiaries' expectations to start the construction phase as soon as possible (Arefian, $2015,2016)$. This became a major problem, given the importance that was given by the government to rapid solutions (Meskinazarian, 2011; Saemian \& Erfanian, 2011).

The source of this conflict lay in the fact that, at an early stage during reconstruction, the KCEO imposed further technical restrictions to the existing national seismic regulations, to be applied in the Bam area. This was done without liaising with other reconstruction participants. As a result, architectural designs under the BAUC's initial architectural guidance and approval by the MC, could not receive approval from the KCEO and vice versa (Arefian, 2015, 2016). As was documented later, the HFIR tried to tackle the problems, but even mediations by the HFIR were not successful (Saemian \& Erfanian, 2011). One of the solutions which ended this conflict and removed this bottleneck was that the MC, finally and reluctantly, accepted the newly introduced KCEO's restrictions (Arefian, 2015, 2016). Nonetheless, this 
conflict had a major influence on how housing reconstruction worked from then on. Figure 3 shows a typical example of a fully completed house as approved by the controllers. Thus, the housing reconstruction program ended up in the production of simple rectangular houses. Although these houses still followed a few basic architectural guidance rules, e.g. by preserving the palm trees and using local materials, the completed houses were far from the initial ideas envisioned by the BAUC, based on traditional architecture in Bam (Arefian, 2016).

\section{Figure 3 near here}

Later studies linked the emergence of this major conflict (i) to the number of participants in the housing reconstruction, (ii) to treating program objectives in isolation, (iii) to the failure in identifying and harmonizing functional interconnections (Arefian, 2016), and (iv) to a lack of mutual understanding of priorities (Arefian, 2015). All this is an elaborated, but unfortunately typical example of institutional fragmentation that characterized the permanent housing experience in Bam. See more in Table 3.

Table 3: Fragmentation in the transitional sheltering and the permanent housing programs in Bam

\begin{tabular}{|c|c|c|}
\hline $\begin{array}{l}\text { Fragmentation } \\
\text { type }\end{array}$ & $\begin{array}{l}\text { Fragmentation in the Transitional } \\
\text { Sheltering Program }\end{array}$ & $\begin{array}{l}\text { Fragmentation in the Permanent } \\
\text { Housing Reconstruction Programme }\end{array}$ \\
\hline \multirow{2}{*}{$\begin{array}{l}\text { Construction } \\
\text { Industry } \\
\text { Fragmentation }\end{array}$} & $\begin{array}{l}\text { Competition on the number, time, and cost } \\
\text { of units. }\end{array}$ & $\begin{array}{l}\text { Conflict and confrontation between two } \\
\text { controller organisations (MC \& KCEO) }\end{array}$ \\
\hline & $\begin{array}{l}\text { The existence of different experts in low- } \\
\text { cost housing, Defense Industry, pre- } \\
\text { fabricated unit designers and developers. }\end{array}$ & $\begin{array}{l}\text { The existence of too many organizations } \\
\text { for undertaking technical, financial and } \\
\text { administrative tasks }\end{array}$ \\
\hline \multirow{3}{*}{$\begin{array}{l}\text { Procurement } \\
\text { Fragmentation }\end{array}$} & $\begin{array}{l}\text { Invitation of organizations, companies, and } \\
\text { NGOs to provide shelters fast and low- } \\
\text { priced. }\end{array}$ & Separate design and construction phases \\
\hline & $\begin{array}{l}\text { An instance of Defense Industry and one } \\
\text { private company on the provision of camps } \\
\text { of pre-fabricated units rather than separated } \\
\text { units in the yards. }\end{array}$ & Numerous small contractor teams \\
\hline & $\begin{array}{l}\text { The existence of a weak link between the } \\
\text { HFIR, as an experienced contractor, and the } \\
\text { other contractors who had no particular } \\
\text { experience in the reconstruction. }\end{array}$ & $\begin{array}{l}\text { Lack of contact between consultancies and } \\
\text { contractor teams, }\end{array}$ \\
\hline $\begin{array}{l}\text { Design Project } \\
\text { Fragmentation }\end{array}$ & $\begin{array}{l}\text { The fragmented design of pre-fabricated } \\
\text { units, camps, and isolated units located in the } \\
\text { yards, corresponding to a change in project } \\
\text { briefs. }\end{array}$ & $\begin{array}{l}\text { Sequential approach to design and } \\
\text { construction phases }\end{array}$ \\
\hline $\begin{array}{l}\text { Construction } \\
\text { work } \\
\text { fragmentation }\end{array}$ & $\begin{array}{l}\text { Despite previous experience, there was a } \\
\text { change in policy regarding the types and } \\
\text { locations of transitional housing half way } \\
\text { through the program, thus leading to a break } \\
\text { down of planned production work. }\end{array}$ & $\begin{array}{l}\text { Difficulty in planning and managing the } \\
\text { construction processes after the delays in } \\
\text { the approval stages. Lack of a responsible } \\
\text { supervising architect familiar with the } \\
\text { designs. }\end{array}$ \\
\hline
\end{tabular}


Taken together, the results shown in Table 3 highlight the extremely negative consequences of deviating from an established plan. These consequences cascade from one level to the next, where it becomes increasingly difficult to carry out any effective corrective measures. Of course, in the circumstances that prevail after a disaster, it is only to be expected that there be changes; the lesson is that plans particularly those established in anticipation of a possible disaster - should include a management strategy that allows for uncertainty and consequent variations in time and place.

\section{Mid-term and long-term impacts of the reconstruction program}

The theoretical concepts associated with institutional fragmentation in construction can be systematically applied to the individual phases of a reconstruction program such as the provision of transitional sheltering and permanent housing, as we have shown. However, one has to ask what happens at the end of the "official" reconstruction program, when the organizations that had been put in place with their skills and know-how, withdrew or were closed, bearing in mind that "recovery is a complex process with an ill-defined endpoint and no agreed upon measure of success" (Rubin, 1985, cited by Johnson and Hayashi 2012, p. 215). Is there then a transition to a state of normality, in which construction continues "as usual", that is to say as prior to the earthquake with its endemic fragmentation? This issue is important in a project management perspective, where projects have determined beginnings and ends, and are devised to attain set objectives. In reconstruction, stakeholders deal with programs (groups of coordinated projects), the endpoints of which are not necessarily well established. What happens afterwards is a question which somewhat naturally falls outside the scope of conventional project management and conventional views of institutional fragmentation.

Looking at the reconstruction program of Bam at first, it appeared that all the new houses that were being built during the reconstruction phase were rigorously complying with the seismic building codes and one could therefore assume that they would withstand earthquakes - if only because of the HFIRappointed inspectors' work. But the biggest challenge turned out to be the long term continuity of building with earthquake-resistance and the concomitant understanding by all implicated builders of how to so.

The seismic building codes were severely enforced by continuous inspections from KCEO during the reconstruction period; however, a driving force for subsequently maintaining the appropriate implementation remained unaddressed. How could it be ensured that contractors would maintain the proper practice of implementation when the rigorous external controls are removed? How can the continuity of earthquake-safe building knowledge be maintained in a context such as Bam?

Careful observations from within contractor firms, and by field studies and interviews over a longer period after the official end of the reconstruction program, show that the builders received a considerable degree of information about safe construction, but the practice of safe-construction lacked meaning for them. They knew which components were important for reinforcing the structure against seismic shocks, but they did not necessarily understand what were the underlying principles for using those components. As a result, structures were overdone, under the misconception that the bigger the structural elements, the stronger the building (see Figure 4) and over-sizing concrete reinforcing was a very common practice in the popular housing sector. In other words, although it seemed that the local masons and general contractors knew what measures to take to build in anticipation of earthquakes, they did not appear to comprehend the concepts behind these principles.

\section{Figure 4 near here}

This situation clearly demonstrated the well-known distinction between "knowing" and "knowledge". Once again, new techniques were put into practice within the community of builders without knowing sufficiently why they were doing what they were doing, but unlike the situation that prevailed before the earthquake when insufficient and improper techniques were used, now they used more than sufficient technical features, but improperly and wastefully. Although the local builders' understanding of the earthquake-resistant construction (what to do) was present, the reconstruction program failed to transfer the knowledge of earthquake-resistant construction (why and how to do it). 


\section{Discussion and Conclusions}

The reconstruction of Bam took place in an environment that was expected to be conducive to collaboration between participants. The reconstruction program also shows how the HFIR benefited from its accumulated experience as a longer-term intervener, thus leading to a higher chance of success and to the creation of better solutions. In fact, accumulated experience vested in the lead agency (HFIR), feedback from previous reconstruction programs, and the backing of a central government willing to become involved, combined to establish a framework within which administrators, professionals and enterprises should be able to work in harmony. Observations show, however, how in spite of policies, institutional fragmentation after the disaster hindered collaboration between participants in two different phases. The endemic construction-related institutional fragmentation could not be easily brushed aside. For example, the administrative agencies had difficulty in agreeing on common principles and applying them in a coordinated fashion; as a result, the professionals, as reported, had to cope with changes to the ground rules in a situation that was already - by its very nature - fraught with complexities.

Some implications in practice and theory can be drawn from studying the reconstruction experience in Bam. First, empirical findings show that there is a significant difference between the publicly shared vision of a national effort to reconstruct in the context of a historic site, and the realities of arranging for construction work to be done in the field rapidly, whether by professionals or enterprises. This difference is reflected in the contractual arrangements that are established between the parties - at the level of the reconstruction program as a whole and at the level of the individual projects that make it up. These are the contracts that define who does what and under what conditions; together they form the procurement system.

Second, results reveal that the specific conditions after disasters such as the scale of projects, emphasis on time, emphasis on reducing future disaster risks, and socio-political pressures make institutional fragmentation highly inevitable in post-disaster reconstruction projects. For instance, the emphasis on providing transitional shelters during the shortest time possible after the disaster in Bam required inviting a large number of construction unit designers and developers with distinct capacity and experience levels. In order to ensure the provision of required units on schedule, the government intensified the competition on the number, time, and cost of units, causing construction industry and procurement fragmentation during the transitional sheltering phase. Similarly, socio-political pressures along with the emphasis on reducing future disaster risks led to conflict and confrontation between two controller organizations (MC and KCEO) during the permanent housing phase. Again, the emphasis on time separated design and construction phases, involved numerous small contractor teams, and broke off contact between consultancies and contractor teams.

This research explains three out of four different levels of fragmentation in post-disaster reconstruction in Bam, including: construction industry fragmentation, traditional procurement fragmentation, and design project fragmentation. However, the findings have to be taken with prudence. This study suffered from several limitations, including difficulty accessing key participants, and scarce information about the involved NGOs. However, one of the most important limits of this study is that the regular construction projects in Iran were not examined, and results cannot explain how the institutional fragmentation that was found in this reconstruction program compares with regular construction projects in Iran. Construction work fragmentation, even though it is included in our conclusions, should be regarded as tentative; in any case it is strongly influenced by procurement fragmentation. Indeed, further studies need to be conducted to compare institutional fragmentation between regular and post-disaster construction projects in a similar context.

This study explores leading causes of the absence of collaboration and the lack of the sharing of knowledge and experience in post-disaster reconstruction. It examines the reconstruction project after the 2003 earthquake in Bam, Iran, and explains how fragmentation appeared in Bam. Results show how these levels of fragmentation led to the reported outcomes, which were very different from the publicly shared vision of the reconstruction program. Conflict and confrontation between two controller organizations (MC and KCEO) ended in the excessive emphasis on technical requirements at the expense of designs aimed at respecting and preserving the cultural heritage, as reported regarding the permanent housing program. Findings also point to specific conditions that prevail after disasters - such 
as time and socio-political pressures, and the involvement of numerous stakeholders with different interests and expectations - all of which increase the effects of fragmentation, however endemic, and lead to consequences on the ability to manage the compression of time.

In traditional circumstances, institutional fragmentation in the construction sector is circumvented by the fact that everyone knows that everyone knows what they are supposed to be doing. In reconstruction, however, this is almost inevitably not the case if only because of the number and variety of participants, and it is clear that in such a context, procurement must be systematic, inclusive and comprehensive, covering not only expectations about each participant's tasks, but also about the interfaces - both hierarchical and transversal - that will enable those tasks to be conducted effectively.

Examining the different phases of the Bam case (including the post-program phase) shows that many aspects of project-related work were improvised in response to events that could, or should have been anticipated. That these events can be attributed to fragmentation does not relieve everyone's responsibility to ensure (i) commonly accepted definitions of tasks, (ii) advance identification of interfaces and (iii) proportioned recognition of each participant's knowledge requirements. Instead, there is a need for a clear all-embracing organizational structure, termed "meta-procurement" by Johnson et al. (2005). Successful reconstruction of Bam - and elsewhere - must pass through this meta-procurement filter.

\section{References}

Alwi, S., \& Hampson, K. D. (2003). Identifying the important causes of delays in bulding construction projects.

Amaratunga, D., Haigh, R., Thanurjan, R., \& Indunil P. Seneviratne, L. (2009). The role of knowledge management in post-disaster housing reconstruction. Disaster Prevention and Management: An International Journal, 18(1), 66-77.

Arefian, F. (2015). Organizational design and management for post-disaster reconstruction programs, the case of Bam. (Ph.D. Unpublished $\mathrm{PhD}$ thesis in process for publication), University College of London, London, UK.

Arefian, F. (2016). Getting ready for urban reconstruction: organizing housing reconstruction in Bam. In F. Arefian \& S. H. I. Moeini (Eds.), Urban Change in Iran (pp. 231-248): Springer.

Asgary, A., Badri, A., Rafieian, M., \& Hajinejad, A. (2006). Lost and used post-disaster development opportunities in Bam earthquake and the role of stakeholders.

Babaie, F., \& Kabiri, N. (2011). Design Process in Reconstruction. Tehran: Housing Foundation of Islamic RepublicIn Persian.

Barenstein, J. (2010). Reconstruction Approaches. In A. K. Jha, J. D. Barenstein, P. M. Phelps, D. Pittet, $\&$ S. Sena (Eds.), Safer Homes, Stronger Communities - A Handbook for Reconstructing after Natural Disasters (pp. 93-107). Washington DC: The International Bank for Reconstruction and Development / The World Bank.

Bosher, L., \& Dainty, A. (2011). Disaster risk reduction and 'built-in'resilience: towards overarching principles for construction practice. Disasters, 35(1), 1-18.

Brown, J. S., \& Duguid, P. (2001). Structure and Spontaneity: knowledge and organization. Managing industrial knowledge: Creation, transfer and utilization, 44-67.

CCQ. (2015). An Excisting Industry - Thousands of Stimulating Jobs (2015-2016 ed.). Montreal, Canada: Communications Directorate - Commission de la construction du Québec (CCQ)

Chang, Y., Wilkinson, S., Potangaroa, R., \& Seville, E. (2010). Resources and capacity: lessons learned from post-disaster reconstruction resourcing in Indonesia, China and Australia.

Christensen, J. L., Schibany, A., \& Vinding, A. L. (2001). Collaboration between manufacturing firms and knowledge institutions on product development: evidence from harmonised surveys in Australia, Austria, Denmark, Norway and Spain. Innovative Networks, Co-Operation in National Innovation Systems, 253-278.

Davidson, C. H. (1988). Building team. Encyclopedia of Architecture Design, Engineering \& Construction, New York, John Wiley and Sons, 1, 509-515. 
Davidson, C. H., Johnson, C., Lizarralde, G., Dikmen, N., \& Sliwinski, A. (2007). Truths and myths about community participation in post-disaster housing projects. Habitat International, 31(1), $100-115$

Dulaimi, M. F., Y. Ling, F. Y., Ofori, G., \& Silva, N. D. (2002). Enhancing integration and innovation in construction. Building Research \& Information, 30(4), 237-247.

Fallahi, A. (2007). Lessons learned from the housing reconstruction following the Bam earthquake in Iran. The Australian Journal of Emergency Management, 22(1), 26.

Fayazi, M. (2012). Temporary Housing Experience after Bam Earthquake 2003. Tehran: Housing Foundation of Islamic Republic

Fayazi, M., Kikano, F., \& Lizarralde, G. (2015). The Impacts of Post-Disaster Reconstruction Policies on Different Categories of Households in Bam, Iran. Paper presented at the 7th International iRec conference, July 6-8 in the Bartlett Development Planning Unit, University College London

Fayazi, M., \& Lizarralde, G. (2014). The Role of Low-Cost Housing in the Path from Vulnerability to Resilience International Journal of Architectural Research, 7(3), 146-167. Retrieved from http://www.archnet-ijar.net/index.php/IJAR/article/view/56

Forgues, D., \& Koskela, L. (2009). The influence of a collaborative procurement approach using integrated design in construction on project team performance. International Journal of Managing Projects in Business, 2(3), 370-385.

Freeman, R. E. (1983). Strategic management: A stakeholder approach. Advances in strategic management, l(1), 31-60.

Gann, D. M., \& Salter, A. J. (2000). Innovation in project-based, service-enhanced firms: the construction of complex products and systems. Research policy, 29(7), 955-972.

Ghafory-Ashtiany, M., \& Hosseini, M. (2008). Post-Bam earthquake: recovery and reconstruction. Natural Hazards, 44(2), 229-241.

Gottlieb, S. C., \& Haugbølle, K. (2013). Contradictions and collaboration: partnering in-between systems of production, values, and interests. Construction management and economics, 31(2), $119-134$.

Groák, S. (1994). Is construction an industry? Notes towards a greater analytic emphasis on external linkages. Construction management and economics, 12(4), 287-293.

Haller, G., Morales, M., Pfister, R., Garnerin, P., Chipp, P., Guillemot, V., . . . Clergue, F. (2008). Improving interprofessional teamwork in obstetrics: A Crew Resource Management based training programme. Journal of interprofessional care, 22(5), 545-548.

Hayles, C. S. (2010). An examination of decision making in post disaster housing reconstruction. International Journal of Disaster Resilience in the Built Environment, 1(1), 103-122.

Hidayat, B., \& Egbu, C. (2010). A literature review of the role of project management in post-disaster reconstruction. Paper presented at the Procs 26th Annual ARCOM Conference.

Huovila, P., Koskela, L., \& Lautanala, M. (1997). Fast or concurrent: the art of getting construction improved. Lean construction, 143, 159.

Joodi, M. (2010). A Brief Review on Bam Reconstruction Program, presented in the International Recovery Forum on January 1st, 2010. International Recovery Platform (IRP). Kobe, Japan.

Joodi, M. (2011) The role of the Housing Foundation of the Islamic Republic (HFIR) in the phase of temporary housing after Bam Earthquake 2003 /Interviewer: M. Fayazi. The Bam Reconstruction Documentation Project (BRDP), HFIR Tehran.

Katsanis, C. J., \& Davidson, H. (2001). Horizon 2020: Performance Trends for the Professional Practice Firm and for The Building Contractor. Paper presented at the Performance in Product and Practice-Proceedings of the CIB World Building Congress 2001.

KDTF. (2004). The minutes of the Kerman Disaster Task Force (KDTF) meetings on 25 March. 2004. Retrieved from Kerman

KDTF. (2014). The minutes of the Kerman Disaster Task Force (KDTF) meetings on 20 June. 2004. Retrieved from Kerman

Kulatunga, U., Amaratunga, R., \& Haigh, R. (2006). Construction innovation: a literature review on current research. Paper presented at the Sixth International Postgraduate Research Conference in the Built and Human Environment, Delft. var.pag.

Latham, S. M. (1994). Constructing the team. London: HM Stationery Office, pp. 130 
Le Masurier, J., Rotimi, J. O., \& Wilkinson, S. (2006). Comparison between routine construction and post-disaster reconstruction with case studies from New Zealand.

Leoto, F. R., lizarralde, G., \& Herazo-Cueto, B. (2014, 3-7 August 2014). Scope and Limitation of Innovation and Collaboration in Integrated Design (ID) for Architecture. Paper presented at the XXV Worlds Congress of Architecture, International Convention Center Duban South Africa. var.pag.

Lichtig, W. A. (2006). Integrated Agreement for Lean Project Delivery, The. Constr. Law., 26, 25.

Ling, F. Y. Y. (2003). Managing the implementation of construction innovations. Construction management and economics, 21(6), 635-649.

Lizarralde, G. (2015). The Invisible Houses: Rethinking and designing low-cost housing in developing countries: Routledge

Lizarralde, G., Davidson, C., De Blois, M., \& Pukteris, A. (2008). Building abroad: procurement of construction and reconstruction projects in the international context. Paper presented at the Building Abroad: Procurement of construction and reconstruction projects in the international context, Montreal. var.pag.

Löhnert, G., Dalkowski, A., \& Sutter, W. (2003). Integrated Design Process: a guideline for sustainable and solar-optimised building design. Paper presented at the IEA International Energy Agency Task 23 - Optimization of Solar Energy Use in Large Buildings, subtask B, Austria. var.pag.

Mahdian, A. (2010). [The role of the Housing Foundation of the Islamic Republic (HFIR) in Trasitional Sheltering Phase after Bam Earthquake 2003].

Meskinazarian, A. (2011). Social Resilience of Post-Earthquake Bam. King's College London, London, UK.

Mohsini, R., \& Davidson, C. H. (1992). Determinants of performance in the traditional building process. Construction management and economics, 10(4), 343-359.

Mohsini, R., Sirpal, R., \& Davidson, C. (1995). Procurement: A comparative analysis of construction management and traditional building processes: Comparative study of two different procurement processes in Singapore. Building research and information, 23(5), 285-290.

Mossman, A., Ballard, G., \& Pasquire, C. (2010). Lean project delivery-innovation in integrated design \& delivery. Draft for Architectural Engineering and Design Management Special Issue on Integrated Design \& Development Systems (IDDS) [available at http://independent. academia. edu/documents/0095/5229/Mossman, February 2016].

NDTF. (2004). The minutes of the National Disaster Task Force (NDTF) meetings on 10 Jan. 2004. Retrieved from Tehran:

NDTF. (2014). The minutes of the National Disaster Task Force (NDTF) meetings on 03 April. 2004. Tehran, Ministry of Interior Affairs.

Norling, B. (2013). Effective Time Management in Post-Disaster Reconstruction. Paper presented at the Australian and New Zealand Disaster and Emergency Management Conference.

Ofori, G. (1992). The environment: the fourth construction project objective? Construction management and economics, 10(5), 369-395.

Ofori, G. (2002). Construction industry development for disaster prevention and response. Paper presented at the Proceedings of the i-Rec International Conference on Post-Disaster reconstruction: Planning for reconstruction.

Ofori, G. (2012). Contemporary Issues in Construction in Developing Countries: Routledge

Olshansky, R. B., Hopkins, L. D., \& Johnson, L. A. (2012). Disaster and recovery: Processes compressed in time. Natural hazards review, 13(3), 173-178.

Olshansky, R. B., Johnson, L. A., Horne, J., \& Nee, B. (2008). Longer view: Planning for the rebuilding of New Orleans. Journal of the American Planning Association, 74(3), 273-287.

Omidvar, B., Zafari, H., \& Derakhshan, S. (2010). Reconstruction management policies in residential and commercial sectors after the 2003 bam earthquake in Iran. Natural Hazards, 54(2), 289306.

PMI. (2015). Project Management Body of Knowledge (PMBOK® GUIDE): Project Management Institute

Powell, W. W. (1996). Inter-organizational collaboration in the biotechnology industry. Journal of Institutional and Theoretical Economics (JITE)/Zeitschrift für die gesamte Staatswissenschaft, 197-215. 
Pries, F., \& Janszen, F. (1995). Innovation in the construction industry: the dominant role of the environment. Construction management and economics, 13(1), 43-51.

RIBA (Royal Institute of British Architects /Keyte, M., Williams, A., Iredale, R., Davidson, C. and MacDowell, D.). (1964) The Industrialisation of Building. RIBA, Industrialised Building Study Team, London, $40 \mathrm{pp}$.

Rutten, M. E., Dorée, A. G., \& Halman, J. I. (2009). Innovation and interorganizational cooperation: a synthesis of literature. Construction Innovation, 9(3), 285-297.

Saemian, S., \& Erfanian, A. (2011). The Process of Technical Control and Supervision in Reconstruction of Bam. Tehran: Housing Foundation of Islamic Republic In Persian.

Smith, L. G. (2014). Impact assessment and sustainable resource management: Routledge

Statistic Center of Iran. (2003). Summary of Bam Statistic. Tehran: Statistic Center of Iran

Thomassen, M. A. (2003). The economic organization of building processes. Ph.D. thesis, BYG-DTU, Technical University of Denmark. var. pag.

VonMeding, J., McVeigh, A., Amiri, Z., \& Burke, C. (2013). Engaging the commercial construction industry in a post-disaster context| NOVA. The University of Newcastle's Digital Repository.

Witt, E., Sharma, K., \& Lill, I. (2014). Mapping construction industry roles to the disaster management cycle. Procedia Economics and Finance, 18, 103-110.

Yates, J., \& Battersby, L. C. (2003). Master builder project delivery system and designer construction knowledge. Journal of Construction Engineering and Management, 129(6), 635-644.

Yin, R. (2003). Case study research: Design and methods. Sage Publications, Inc, 5, 11. 


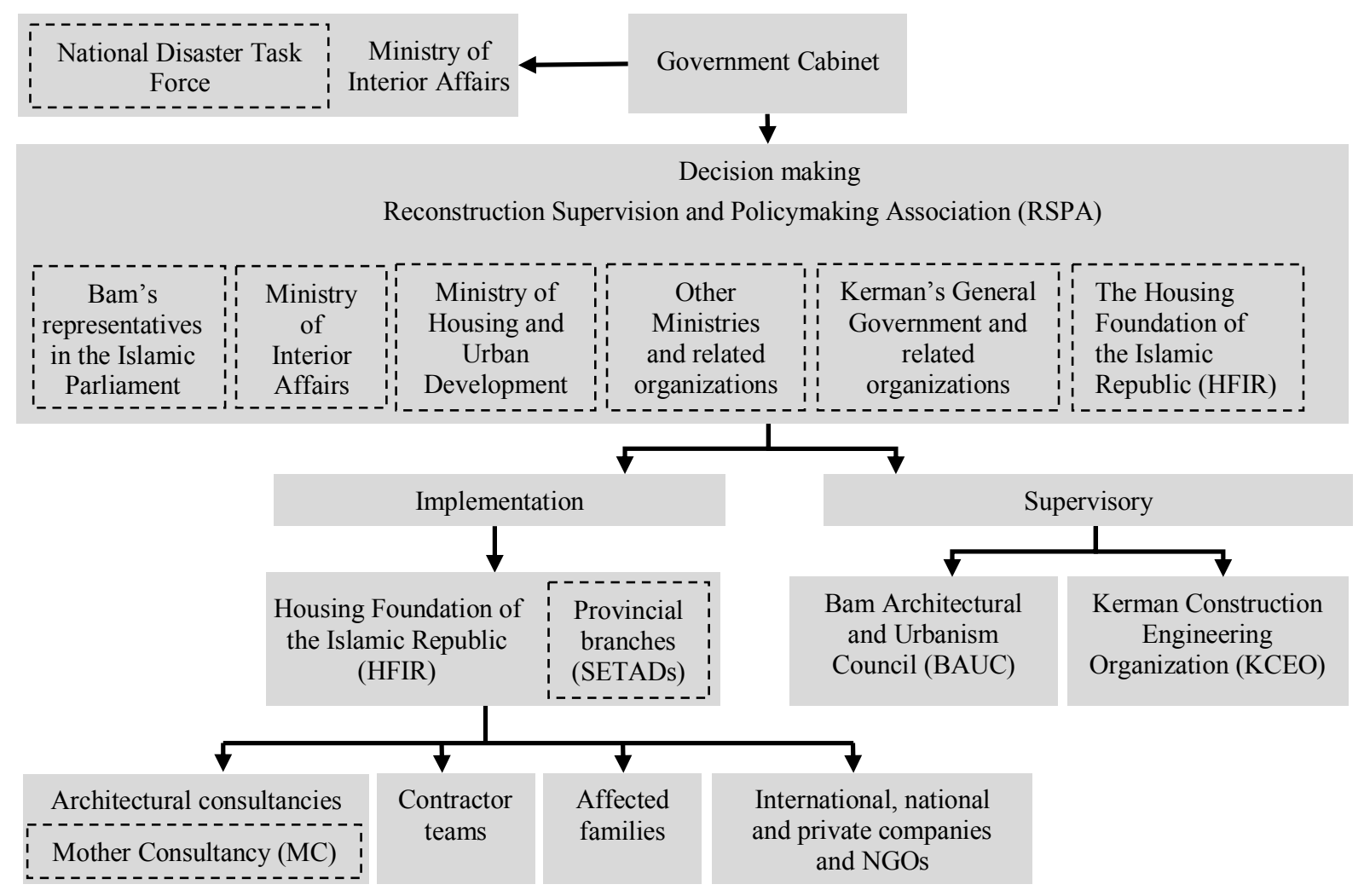

Figure 1: Stakeholders involved in the Bam reconstruction program
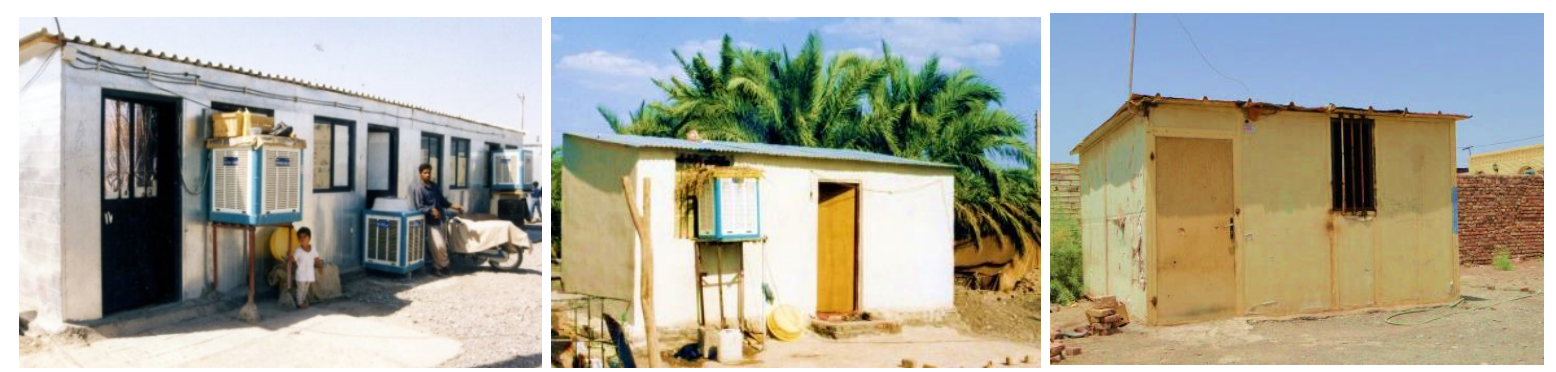

Figure 2: Camps of prefabricated units provided by Defence Industry (Left); units made of steel frames and masonry walls in the yards of destroyed houses, the HFIR's solution (Center); prefabricated units provided in the yards of destroyed houses by one of the private companies (Right). (photos by Fayazi) 


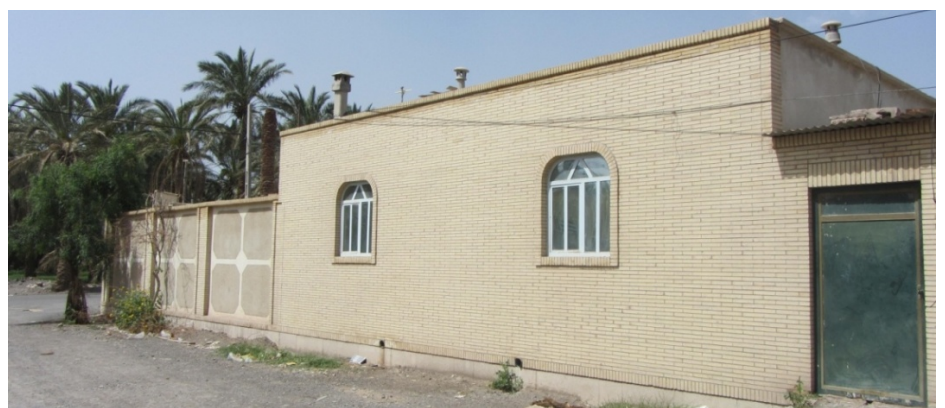

Figure 3 : A typical example of a reconstructed house, lacking the architectural qualities that characterised historic architecture in Bam. (photo by Arefian)
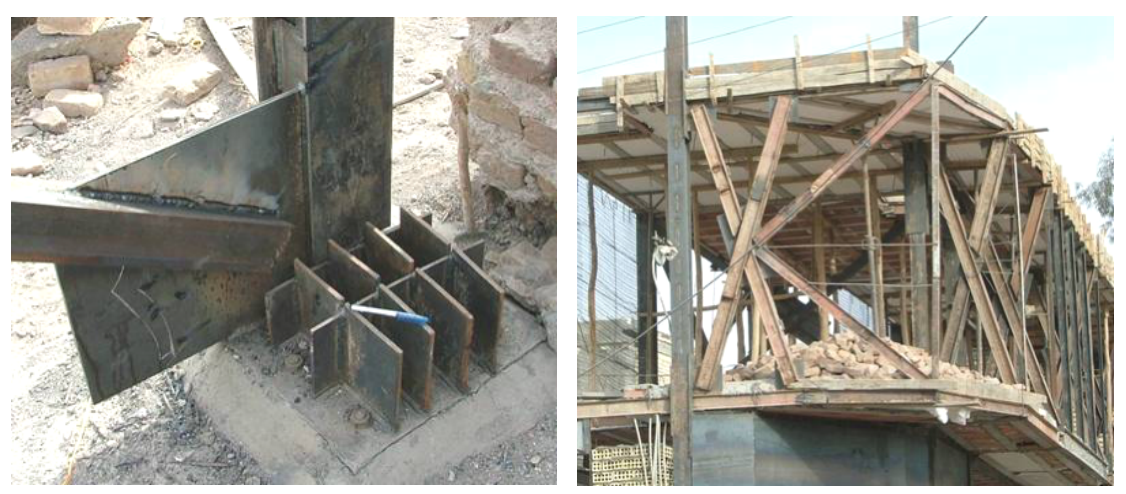

Figure 4: Improper use of reinforcement illustrates the presence of a blind application of safeconstruction knowledge (photos by Gharaati) 